\title{
ISOLASI KITOSAN DARI LIMBAH CANGKANG KEPITING BAKAU (Scylla serrata) DAN APLIKASINYA TERHADAP PENYERAPAN TRIGLISERIDA
}

\author{
Nur Ramadhana Dewi Safitri ${ }^{1}$, Seniwati Dali ${ }^{2}$ dan Muammar Fawwaz ${ }^{1}$ \\ ${ }^{1}$ Fakultas Farmasi Universitas Muslim Indonesia, Makassar \\ ${ }^{2}$ Fakultas MIPA Universitas Hasanuddin, Makassar \\ Email:seniwatid @gmail.com
}

\begin{abstract}
Chitosan is the result of deacetylation process from chitin which it can be found on Crustacean outer shell such as crabs. Chitosan can bind fat if it was consumed by human. The fat-binding ability of chitosan depends on the deacetylation degree. The research have been made into two phases. The first phase, chitosan was made from crab shell using $\mathrm{NaOH}$. The deacetylation degree from chitosan that was made from the earlier process was analyzed with FTIR. The deacetylation degree result of the research was $59.39 \%$ using $\mathrm{NaOH} 50 \%$. The second phase was the process of adsorbing triglycerides using chitosan in 10, 30, 45, and 60 minutes which was analyzed using spectrophotometer UV-Vis. The result of this research showed that the optimum triglycerides with $0.5,1,3$ gram of chitosan was $2.99 \%$, $3.14 \%$, and $3.36 \%$.
\end{abstract}

Keywords : Crab shell, chitosan, deacetylation degree, triglycerides.

\section{PENDAHULUAN}

Wilayah Indonesia sebagian besar terdiri dari lautan yang kaya akan biota laut. Kepiting merupakan salah satu biota laut yang sangat diminati masyarakat karena memiliki kandungan nutrisi yang penting bagi kesehatan. Cangkang kepiting mengandung kitin yang apabila dirubah menjadi kitosan memberikan banyak manfaat, diantaranya sebagai pelangsing. Sifat menonjol kitosan adalah kemampuan mengabsorpsi lemak hingga 4-5 kali beratnya. ${ }^{1}$
Lemak pada dasarmya terbagi atas Low Density Lipoprotein (LDL), High Density Lipoprotein (HDL), dan trigliserida. Trigliserida merupakan penyusun utama minyak nabati dan lemak hewani. Lemak dan minyak adalah trigliserida yang merupakan ester dari gliserol dan asam lemak rantai panjang. Senyawa ini terbentuk dari hasil kondensasi satu molekul gliserol dengan tiga molekul asam lemak. ${ }^{2}$ Trigliserida adalah salah satu jenis lemak utama di dalam darah manusia. Jika terlalu banyak, 
Isolasi kitosan dari limbah cangkang kepiting bakau (Scylla serrata) dan aplikasinya terhadap penyerapan trigliserida

trigliserida akan menumpuk pada bagian-bagian tubuh seperti dinding pembuluh darah dan hati. Trigliserida sangat penting bagi manusia karena tubuh memanfaatkan lemak ini sebagai sumber energi. Trigliserida dihasilkan tubuh dari sumber energi lainnya, yaitu karbohidrat dan dari pencernaan lemak yang terdapat dalam makanan, namun kadar trigliserida yang tinggi akan meningkatkan resiko terserang penyakit seperti serangan jantung dan stroke.

Kitosan termasuk golongan polisakarida. Adanya gugus amina pada kitosan menjadikan kitosan bermuatan parsial positif kuat, yang menyebabkan kitosan dapat menarik molekul-molekul yang bermuatan parsial negatif seperti minyak, lemak dan protein. Sifat inilah yang kemudian membuat kitosan memiliki manfaat yang banyak. Kitosan dan turunannya telah banyak dimanfaatkan secara komersial dalam industri pangan, kosmetika, pertanian, farmasi, pengolahan limbah dan penjernihan air. Perkembangan penggunaan bahan alami, akhir 1970-an, meningkatkan konsumsi kitosan, terlebih dengan beberapa penemuan baru untuk aplikasi kitosan di bidang farmasi dan kesehatan di akhir 1990- an hingga sekarang. Saat ini kitosan amat diminati karena bisa menurunkan kadar kolesterol, asam urat, pengikat lemak sekaligus pelangsing tubuh. ${ }^{1}$

Kitosan merupakan polisakarida alami yang terdiri dari kopolimer glukosamin dan $\mathrm{N}$-asetilglukosamin, dapat diperoleh dari deasetilasi kitin. ${ }^{3}$ Kitosan dapat pula diperoleh dari kitin yang direaksikan dengan $\mathrm{NaOH}^{4}$ Pada proses deasetilasi terjadi substitusi gugus amino $\left(\mathrm{NH}_{2}\right)$. Besarnya substitusi yang terjadi disebut tingkat deasetilasi atau derajat deasetilasi. Keberhasilan proses deasetilasi dipengaruhi oleh konsentrasi $\mathrm{NaOH}$, suhu dan lamanya proses deasetilasi. $^{5}$

Kitin biopolimer alami terbesar kedua yang dapat ditemukan di alam setelah selulosa. Kitin dapat diperoleh dari arthropoda, jamur, dan ragi ${ }^{7}$, tetapi sumber komersial yang penting adalah eksoskleton dari kepiting. ${ }^{8}$ Kandungan kitin pada kulit udang mencapai $42 \%-57 \%$, sedangkan pada cangkang kepiting mencapai $50 \%$ $60 \%$.

Kitin larut dalam asam-asam mineral yang pekat seperti $\mathrm{HCl}, \mathrm{HNO}_{3}$ dan $\mathrm{H}_{2} \mathrm{SO}_{4}$, sedangkan kitosan dapat diperoleh dengan mengkonversi kitin. ${ }^{9}$ Kitin yang diisolasi dari cangkang udang windu mampu menurunkan 
Isolasi kitosan dari limbah cangkang kepiting bakau (Scylla serrata) dan aplikasinya terhadap penyerapan trigliserida

kadar kolesterol kelinci. ${ }^{10}$ Berdasarkan uraian diatas maka perlu dilakukan penelitian mengenai efek kitosan yang diperoleh dari hasil deasetilasi kitin dari cangkang kepiting bakau dalam penyerapan trigliserida.

\section{METODE PENELITIAN}

\section{Alat dan Bahan}

Alat yang digunakan adalah ayakan, batang pengaduk, bola hisap, blender (miyako), corong (Herma), erlenmeyer (Pyrex), gelas ukur (Pyrex), gelas beaker (Pyrex), magnetik stirer, labu ukur (Pyrex), oven (memmert), pipet ukur (Pyrex), pipet volume (Pyrex), sendok tanduk, spektrofotometer Fourier Transform Infra Red (FTIR) (Shimadzu), dan stirer (As One).

Bahan yang digunakan adalah aluminium foil, aseton, aquadest, cangkang kepiting, etanol, $\mathrm{HCl}$ p.a (merck), kertas pH (Universal), kertas saring, kitosan standar (Sigma Aldrich $\mathrm{GmbH}$ ), lemak/gajih kambing, $\mathrm{NaOH}$ p.a (merck), $\mathrm{NaOCl}$ p.a (merck).

\section{Prosedur Penelitian}

Penyiapan sampel

Cangkang kepiting bakau (Scylla serrata) basah yang diambil dari Makassar, Sulawesi Selatan dibersihkan dengan air, dikeringkan lalu dihaluskan dan diayak sampai lolos ayakan 50 mesh atau diameter rata-rata $0,356 \mathrm{~mm}$. Selanjutnya dilakukan tahap deproteinasi, demineralisasi, depigmentasi, dan deasetilasi. ${ }^{11}$

\section{Pembuatan Kitin}

\section{Deproteinasi}

Proses ini dilakukan pada suhu $60-70^{\circ} \mathrm{C}$ dengan menggunakan larutan $\mathrm{NaOH} 1 \mathrm{M}$ dengan perbandingan serbuk kepiting dengan $\mathrm{NaOH}=$ 70:700 (gr serbuk/mL NaOH) sambil diaduk selama 60 menit. Kemudian campuran dipisahkan dan disaring untuk diambil endapannya. Endapan dicuci dengan aquadest sampai $\mathrm{pH}$ netral. Kemudian disaring dan endapannya dikeringkan. ${ }^{12}$

\section{Demineralisasi}

Penghilangan mineral dari hasil deproteinasi dilakukan pada suhu 60$70^{\circ} \mathrm{C}$ dengan menggunakan larutan $\mathrm{HCl}=70: 700$ (gr serbuk $/ \mathrm{mL} \mathrm{HCl})$ sambil diaduk selama 120 menit. Selanjutnya disaring untuk diambil endapannya. Endapan dicuci dengan aquadest sampai $\mathrm{pH}$ netral, kemudian disaring dan endapannya dikeringkan. ${ }^{12}$

\section{Depigmentasi}

Endapan hasil demineralisasi ditambahkan aseton kemudian dibleaching (pemutihan) dengan $0,315 \% \mathrm{NaOCl}$ (w/o) selama 5 menit pada suhu kamar. Kemudian dicuci 
Isolasi kitosan dari limbah cangkang kepiting bakau (Scylla serrata) dan aplikasinya terhadap penyerapan trigliserida

dengan aquadest hingga $\mathrm{pH}$ netral lalu disaring dan diambil endapannya. Endapan yang terbentuk merupakan senyawa kitin. ${ }^{12}$

\section{Deasetilasi kitin menjadi kitosan}

Kitin yang telah dihasilkan pada proses diatas dimasukkan dalam larutan $\mathrm{NaOH}$ dengan konsentrasi $50 \%$ (berat) pada suhu $90-100^{\circ} \mathrm{C}$ sambil diaduk kecepatan konstan selama 60 menit. Hasilnya berupa slurry disaring, endapan dicuci dengan aquadest lalu ditambah larutan $\mathrm{HCl}$ encer agar $\mathrm{pH}$ netral kemudian dikeringkan. Hasil yang diperoleh merupakan senyawa kitosan. ${ }^{12}$ Kitosan yang telah didapat dianalisis dengan menggunakan spektrofotometer FTIR untuk mengetahui derajat deasetilasinya. Untuk menentukan derajat deasetilasi (DD) digunakan metode garis Domzy dan Robert: ${ }^{12}$

$\mathrm{DD}=100-\mathrm{A} 1 \mathrm{~A} 2 \times 115$ dengan,

$A: \log (\mathrm{Po} / \mathrm{P})=$ absorbansi

A1 :Absorbansi pada panjang gelombang 1500-1650 $\mathrm{cm}^{-1}$ untuk serapan gugus amida/asetamida $\left(\mathrm{CH}_{3} \mathrm{COONH}^{-}\right)$

A2 :Absorbansi pada panjang gelombang 3000-3500 $\mathrm{cm}^{-1}$ untuk serapan gugus hidroksil/amin $\left(\mathrm{OH}^{-}\right.$ , $\mathrm{NH}_{2}$ )

\section{Penyerapan Trigliserida}

Sebanyak $1 \mathrm{~kg}$ lemak/gajih yang berasal dari daging kambing dipanaskan pada suhu tetap $60^{\circ} \mathrm{C}$ hingga menjadi lemak cair sebanyak $250 \mathrm{~mL}$. Kadar trigliserida dalam lemak mula-mula dianalisis. Selanjutnya dilakukan penyerapan trigliserida dengan menggunakan kitosan. Dalam penyerapan ini dilakukan ekstraksi dengan memasukkan masing-masing $0,5 \mathrm{gr}, 1$ gr, dan 3 gr kitosan kedalam beaker glass yang berisi lemak kambing cair sebanyak $50 \mathrm{~mL}$, diaduk dan suhu operasi dijaga tetap $60^{\circ} \mathrm{C}$, waktu penyerapan divariasi masing-masing 10, 30, 45, dan 60 menit, selanjutnya dilakukan proses penyaringan, filtratnya diambil untuk dianalisis kandungan trigliseridanya dengan Spektrofotometri UV-Vis. ${ }^{12}$

Hasil penyerapan trigliserida pada lemak kambing oleh kitosan dapat dinyatakan dalam persen penyerapan dengan rumus sebagai berikut :

\%penyerapan $=($ absorban lemak $)-$ (absorban kitosan + lemak) absorban lemak x $100 \%$. 
Isolasi kitosan dari limbah cangkang kepiting bakau (Scylla serrata) dan aplikasinya terhadap penyerapan trigliserida

\section{HASIL PENELITIAN}

Tabel 1. Derajat deasetilasi (DD) kitosan standar dan sampel kitosan hasil isolasi.

\begin{tabular}{ccc}
\hline No & Sampel derajat & Deasetilasi (\%) \\
\hline 1 & Kitosan standar (Sigma) & 55.29 \\
2 & Kitosan Hasil isolasi & 59.39 \\
\hline
\end{tabular}

Tabel 2. Hasil analisis gugus fungsi kitosan dari cangkang kepiting bakau menggunakan kondisi optimum pada proses deasetilasi.

\begin{tabular}{ccc}
\hline \multirow{2}{*}{ Gugus fungsi } & \multicolumn{2}{c}{ Bilangan gelombang $\left(\mathbf{c m}^{-1}\right)$} \\
\cline { 2 - 3 } & Kitosan standar & Sampel (NaOH 50\%) \\
\hline $\mathrm{OH}$ & 3444 & 3448 \\
$\mathrm{~N}-\mathrm{H}$ ulur & 2879 & 2923 \\
$\mathrm{C}-\mathrm{H}$ ulu & 2360 & 2359 \\
$\mathrm{NH}_{2}, \mathrm{~N}-\mathrm{H}$ & 1647 & 1643 \\
\hline
\end{tabular}

Tabel 3. Pengaruh massa kitosan di dalam $50 \mathrm{~mL}$ sampel lemak kambing terhadap penyerapan kadar trigliserida (\%), dengan waktu penyerapan 10, 30, 45, dan 60 menit.

\begin{tabular}{|c|c|c|c|c|}
\hline \multirow{2}{*}{ Berat sampel (gram) } & \multicolumn{4}{|c|}{ Waktu penyerapan trigliserida (menit) } \\
\hline & 10 & 30 & 45 & 60 \\
\hline 0.5 & $2.62 \%$ & $2.63 \%$ & $2.78 \%$ & $2.99 \%$ \\
\hline 1 & $2.59 \%$ & $2.82 \%$ & $3.14 \%$ & $3.14 \%$ \\
\hline 3 & $2.99 \%$ & $2.99 \%$ & $3.30 \%$ & $3.36 \%$ \\
\hline
\end{tabular}

\section{PEMBAHASAN}

Kepiting bakau (Scylla serrata) adalah jenis kepiting yang hidup di habitat mangrove/hutan bakau. Scylla serrata merupakan komoditas ekspor disamping rajungan (Portunus pelagicus). Bila rajungan mempunyai nilai ekonomis penting sebagai daging dalam kaleng atau dalam keadaan beku, maka kepiting bakau dapat dipasarkan dalam keadaan hidup karena lebih tahan hidup di luar air. ${ }^{13}$

Bukan hanya daging kepiting yang mempunyai nilai komersil, cangkangnya pun mempunyai nilai ekonomis tinggi. Cangkang kepiting diekspor dalam bentuk kering sebagai sumber kitin, kitosan dan karotenoid 
Isolasi kitosan dari limbah cangkang kepiting bakau (Scylla serrata) dan aplikasinya terhadap penyerapan trigliserida

yang dimanfaatkan oleh berbagai industri sebagai bahan baku obat, kosmetik, pangan, dan lain-lain. Bahan-bahan tersebut memegang peran sebagai antivirus dan antibakteri dan juga digunakan sebagai obat untuk meringankan dan mengobati luka bakar, selain dapat digunakan sebagai pengawet makanan yang murah dan aman. ${ }^{14}$ Cangkang kepiting merupakan sumber potensial pembuatan kitin dan kitosan. Kitosan merupakan hasil deasetilasi kitin yang diperoleh dengan menggunakan basa kuat seperti $\mathrm{NaOH}$, selanjutnya kitosan yang telah diperoleh dianalisis dengan spektrofotometer FTIR untuk mengetahui derajat deasetilasi. ${ }^{4}$

Penentuan derajat deasetilasi kitosan dengan menggunakan $\mathrm{NaOH}$, sampel dibuat pellet dalam bubuk $\mathrm{KBr}$ kemudian ditentukan spektrumnya. Untuk menentukan derajat deasetilasi digunakan metode garis oleh Domszy dan Robert. ${ }^{12}$

Dari data pada Tabel 1 terlihat bahwa derajat deasetilasi yang diperoleh dari kitosan cangkang kepiting bakau (Scylla serrata) dengan konsentrasi $\mathrm{NaOH} 50 \%$ yaitu sebesar 59,39\%. Proses deasetilasi merupakan proses pembentukan kitosan dari kitin menggunakan $\mathrm{NaOH}$ untuk mengganti gugus asetamida dengan gugus amino.

Pada Tabel 2, spektrum IR dari sampel menggunakan $\mathrm{NaOH} 50 \%$ dibandingkan dengan spektrum IR dari kitosan standar, maka dapat disimpulkan bahwa sampel tersebut adalah kitosan. Pada spektra infra merah kitosan, pita serapan pada bilangan gelombang $3448,84 \mathrm{~cm}^{-1}$ merupakan vibrasi $\mathrm{NH}$ amina primer. Pita-pita serapan tajam pada bilangan gelombang 2923,22 $\mathrm{cm}^{-1}$ merupakan vibrasi rentangan $\mathrm{C}-\mathrm{H}$ alkana, sedangkan pita serapan tajam pada bilangan gelombang $2359,98 \mathrm{~cm}^{-1}$ merupakan akibat dari vibrasi rentangan $\mathrm{NH}$ dari amina. Pita serapan 1643,41 $\mathrm{cm}^{-1}$ merupakan vibrasi dari $\mathrm{NH}$ amida primer. Vibrasi $\mathrm{NH}$ amina sekunder memberikan serapan pada bilangan gelombang $1550,82 \mathrm{~cm}^{-1}$. Serapan gugus amida lebih kecil daripada serapan gugus hidroksida karena ikatannya lemah. Terlihat bahwa serapan pada daerah $1643.41 \mathrm{~cm}^{-1}$ semakin lemah dan menandakan deasetilasi mendekati sempurna.

Menurut Hudson dalam Fitri (2005) kitin terdeasetilasi > $50 \%$ maka disebut kitosan. Dari hasil penelitian diperoleh derajat deasetilasi kitin dari cangkang kepiting bakau adalah 59,39 
Isolasi kitosan dari limbah cangkang kepiting bakau (Scylla serrata) dan aplikasinya terhadap penyerapan trigliserida

$\%$, maka dapat dianggap sebagai kitosan. ${ }^{15}$

Hasil dari penyerapan trigliserida pada lemak kambing, seperti ditunjukkan pada Tabel 3 bahwa waktu penyerapan 60 menit dengan massa kitosan $3 \mathrm{gr}$ menunjukkan penurunan kadar trigliserida yang paling tinggi yaitu sebesar 3,36 \%. Pengaruh massa kitosan masing-masing sebanyak 0,5 , 1 dan $3 \mathrm{gr}$ berpengaruh secara positif terhadap penyerapan trigliserida. Dari data diperoleh bahwa semakin banyak massa kitosan yang digunakan dan juga semakin lama waktu perendaman, maka persen penyerapannya semakin meningkat.

\section{KESIMPULAN}

Derajat deasetilasi kitosan dari limbah cangkang kepiting bakau (Scylla serrata) dengan menggunakan $\mathrm{NaOH} 50 \%$, yaitu 59,39\%. Kitosan yang paling baik dalam penyerapan trigliserida lemak kambing yaitu kitosan dengan massa $3 \mathrm{gr}$ dengan presentase penyerapan trigliserida sebesar 3.36\% pada menit ke 60 .

\section{DAFTAR PUSTAKA}

1. Rismana E. Serat Kitosan Mengikat Lemak. Jakarta : Badan Pengkajian dan Penerapan Teknologi, 2008.

2. Yazid E, Nursanti L. Penuntun Praktikum Biokimia untuk
Mahasiswa Analisis.Yogyakarta, 2006.

3. Khan, et al. Reporting Degree of Deacetylation Values of Chitosan: the Influence of Analytical Methods. J Pharm Pharmaceut Sci 2002.

4. Marganof. Potensi Limbah Udang sebagai Penyerap Logam Berat (Timbal, Kadmium, dan Tembaga) di Perairan.

http://rudyct.topcities.com/pps702 71034/marganofhtm.2003.

5. Matheis T, Killay A, Meny S., Khitosan dari Limbah Kulit Udang Windu (Panaeus monodon) sebagai Adsorben Fenol. Journal Alchemy 2006.

6. Fernandez and Kim SO. Physicochemical and Functional Properties of Crawfish Chitosanase Effected by Different Processing Protocol (Thesis). Seoul National University : The Departement of Food Science, 2004.

7. Kim SD, Yonn PB. Effect on The Removal of $\mathrm{Pb}^{+2}$ from Aqueous Solution by Crab Shell J Of Chem Tech and Biotech 2001.

8. Yuly K. Mengenal Lebih Dekat Kitosan, http://www.pikiranrakyat.com/cetak/ 2006/012006/26/cakrawala/la. 2006.

9. Fawwaz M. Efek Antihiperkolesterolemia Kitin Cangkang Udang Windu (Penaeus monodon) Pada Kelinci (Oryctolagus Cuniculus) Secara In Vivo. Jurnal As-Syifaa 2013;05.

10. Weska RF, Moura JM. Optimation of Deasetylation in the Production of Chiltosan from Shrimp Waste. 
Isolasi kitosan dari limbah cangkang kepiting bakau (Scylla serrata) dan aplikasinya terhadap penyerapan trigliserida

Journal Foad Enginering 2006; 80(3):749-753.

11. Hargono, Abdullah, Sumantri I. Pembuatan Kitosan Dari Limbah Cangkang Udang Serta Aplikasinya Dalam Mereduksi Kolesterol Lemak Kambing. 2008.

12. Juwana S. Penelitian Budi Daya Rajungan dan Kepiting: Pengalaman Laboratorium dan lapangan, Prosiding Simposium Interaksi Daratan dan Lautan,
Jakarta: Lembaga IImu Pengetahuan Indonesia, 2004.

13. Muskar YF. Kepiting Lunak Berkat Bayam. www.KepitingLunakBerkat-Bayam.Html. Diunduh tanggal 20 Maret 2011. 2007.

14. Fitri K. Kajian Adsorpsi dan Desorpsi Ag $\left(\mathrm{S}_{2} \mathrm{O}_{3}\right)_{23}$ dalam Limbah Fotografi pada dan dari Adsorben Kitin dan Asam Humat Terimobilisasi pada Kitin (Tesis). Yogyakarta: Universitas Gadjah Mada, 2005. 